\title{
Influence of Design and Social Factors of Store Atmospherics on Impulse Buying Behavior in Sports Goods Retailing
}

\author{
Neethu Jose, F. J. Peter Kumar, Merlin B Joseph
}

\begin{abstract}
Researchers have been very much interested in the field of store atmospherics for the past several years. According to Sharma and Stafford (2000), store atmosphere can be defined as the ability of retailers to attract prospective customers to the store repeatedly and prompt them to do purchase. Another definition by Greeland and McGoldrick (2006) is that all the physical appearance of a store can be coined into a term known as store atmospherics. According to JooPark,Eun ,Eun Young Kim,Judith Cardona Forney(2006) Impulse buying is an unplanned,sudden,compelling behavior of a customer to buy a product. Impulse buying can occur due to the persistent urge and emotions of a customer at the time of purchase (Sultan, Abdullah J,JeffJoireman and David E.Sportt (2012))
\end{abstract}

The study mainly focuses on the influence of design and social factors on impulse buying behavior. Store atmospheric factors has been classified into ambient factors, design factors and social factors(Baker, Grewal\&Parasuraman, 1994)(Baker, Parasuraman, Grewald Voss, 2002) on the basis of previous studies conducted by various researchers. This study focuses on the influence of design and social factors of store atmospherics on Impulse Buying Behavior.lighting, music, and color are the variables considered under design factors .Social factors are nothing but appearance and behavior of personnel and other customers at the store.

This study will be useful for sports goods retailers because impulse buying can helps in increasing sales. The study also discusses on the comparative influences of individual constructs within design and social factors specifically to sports goods retailing.

Keywords:-Store atmospherics. Impulse buying, design factors, social factors

\section{INTRODUCTION}

In today's competitive environment it is very difficult for a retail store to survive.Many researchers have done various studies on the issue and has come up with different models.In the new scenario of retail management store atmospherics has an important role to play.Its effect on Impulse Buying Behaviour of customers has been studied for several decades.The only reason why the influence of store atmospherics is studied again and again is nothing but its importance in creating impulse buying and their by boosting the sales of retail outlets.

Store Atmospherics has been identified as a retail store personality(P. Martineau(1958)).According to L. Aron(1961) store atmospherics include tangible and intangible functional

Revised Version Manuscript Received on 10 September, 2019.

Neethu Jose, Neethu Jose (Research Scholar, Karunya University, Coimbatore), Tamil Nadu, India.

F.J.Peter Kumar, Associate Professor \& Research Supervisor,Karunya School of Management,KarunyaUniversity,Coimbatore Tamil Nadu, India.

Merlin B Joseph, (Assistant Professor,Department Of Business Administration,SBCollege,Changanacherry, Tamil Nadu, India. qualities provided in the retail outlets.L. W. Turley and R. E. Milliman(2007) in their study identified store atmospherics as a combination of physical look, plan, song, mild, fragrance, shading, floor, hold format, engineering structure, and inner layout.H. Skandrani, N. B. D. Mouelhi and F. $\operatorname{Malek}(2011)$ in their research reasoned that store atmospherics affects Impulse buying and this therefore make store loyalty.A. Carida, T. R. Spena, M. Melia and Colurcio(2010) distinguished the general importance of save atmospherics at the selection of the store.

As in keeping with Vohs\&Faber( 2003) and Parboteeah( 2005) strain purchasing is spontaneous that may be a consumer purchases object that isn't in his/her shopping listing. Accordingto D. W. Rook and R. J. Fisher (1995) unstructured buys can be characterized as motivation shopping. W. Rook(1987) distinguished stress shopping for as an accidental shopping preference in exam with an organized buying. As steady with S. E. Beatty and M. E. Ferrell(1998) electricity shopping is at the minute preference an it's miles laid low with various factors, as an example, preserve atmospherics and motivation shopping tendency.J. Dough puncher, D. Grewal and A. Parasuraman(1994),A. Sharma and T. F. Stafford(2000), okay. Yildirim, A. Akalin and M. L. Hidayetoglu(2007)has taken into consideration the effect of keep atmospherics on Impulse shopping for behavior.

there are numerous investigations which have tended to the effect of shop atmospherics on Impulse buying Behaviour.This have a observe walls variables of hold atmospherics into shape and social elements and the grouping relies upon on the examination led via way of J. Bread prepare dinner dinner, D. Grewal and A. Parasuraman(1994).In his exploration Baker recognizes elements of keep atmospherics as vibe detail,layout variables and social elements.Many analysts has prominent the importance of weather factors on motivation shopping however configuration elements and social factors has been given little importance.This paper considers the issue and concentrates the effect of configuration elements and social elements on Impulse purchasing behavior.

\section{WRITING EVALUATE}

\subsection{Store Atmospherics}

Published By: 
numerous scientists have led examines on save atmospherics. As indicated via Areni and Kim (1993) track is a full-size variable of save atmospherics.Chebat, Dube and Hui( 1997) likewise outstanding track as a store barometrical variable. As indicated through Bellizzi, Crowley and Hasty( 1983) shading is a variable of preserve atmospherics. Titus and Everett (1995) identifiedlighting as a variable of keep atmospherics. AccordingtoSmith(1989) lighting triggers pressure purchasing. The more part of the investigations on store atmospherics depends on Baker, D. Grewal and A. Parasuraman(1994) wherein keep barometrical additives are prepared into configuration elements ,encompassing elements and social variables.

\section{2. pressure buying conduct}

diverse analysts have handled Impulse shopping for conduct of customers in severa manner. As indicated via the use of Tinne, WahidaShahan (2011) pressure buying is the impromptu. as an instance clients never plan their purchase in advance.Park, EunJoo, Eun younger Kim, Venessa Martin Funches, and William Foxx(2012) characterizes force buying as an unconstrained behavior in which customers all of the sudden picks an object. SimilarlyTifferet, Sigal, and Ram Herstein(2012) distinguishes energy shopping as an surprising conduct of customer.Vohs, Kathleen D., and Ronald J. Faber(2007) acknowledges motivation purchasing a regular preference of clients to buy an object. in this studies energy buying is contemplated based totally on of its traits, as an example, unplanned,unexpected,compelling and constant desire

\section{2.three Conceptual Framework}

\section{3. goals OF THE examine}

1. To research the effect of configuration components of maintain atmospherics on Impulse buying behavior of video games products in shops.

2. to analyze the effect of social elements of hold atmospherics on Impulse buying conduct of video games merchandise in stores.

3. To examination the close to affects of person builds internal plan elements on Impulse shopping for conduct of video games merchandise in shops.

4. To examination the close to impacts of character builds internal social elements on Impulse buying behavior of video games merchandise in shops.

\section{4. idea TO BE tested}

The accompanying theories have been applied for the studies;

hypothesis 1:

HO:

The design elements of save Atmospherics might no longer have noteworthy effect on the Impulse buying behavior of games merchandise in shops.

\section{hypothesis 2:}

HO:

The Social elements of keep Atmospherics doesn't have noteworthy impact at the Impulse buying conduct of video video games products in retail outlets.

hypothesis three:

HO:

impartial builds of layout elements (lighting fixtures, track,shade) could no longer have noteworthy impact on Impulse buying behavior of video games merchandise in stores.

\section{speculation 4:}

HO:

independent builds of SocialFactors (personnel, patron Crowding) does now not have noteworthy effect on Impulse buying behavior of video games products in stores.

\section{UNIT OF analysis}

customers who have offered sports activities merchandise from video games products stores with great reference to Kottayam locale.

\section{6. facts series}

A sum of 250 questionnaireswere circulated from which 234 had been finished and implemented for the exam. A five component likert scale became applied to check in every problem .The reactions were caught through the bulletins with respect to self sustaining (keep Atmospherics) and ward variable (Impulse buying conduct) within the check..26 causes have been carried out for the equivalent.

7. examination AND DISCUSSIONS. 
International Journal of Recent Technology and Engineering (IJRTE) ISSN: 2277-3878, Volume-8, Issue-2S11, September 2019

\begin{tabular}{|l|l|l|l|}
\hline DEMOGRAPHIC & PERCENT (\%) & $\begin{array}{l}\text { DEMOGRAPHIC } \\
\text { VARIABLES }\end{array}$ & PERCENT (\%) \\
\hline Gender & & Occupation & \\
& & \\
\hline
\end{tabular}

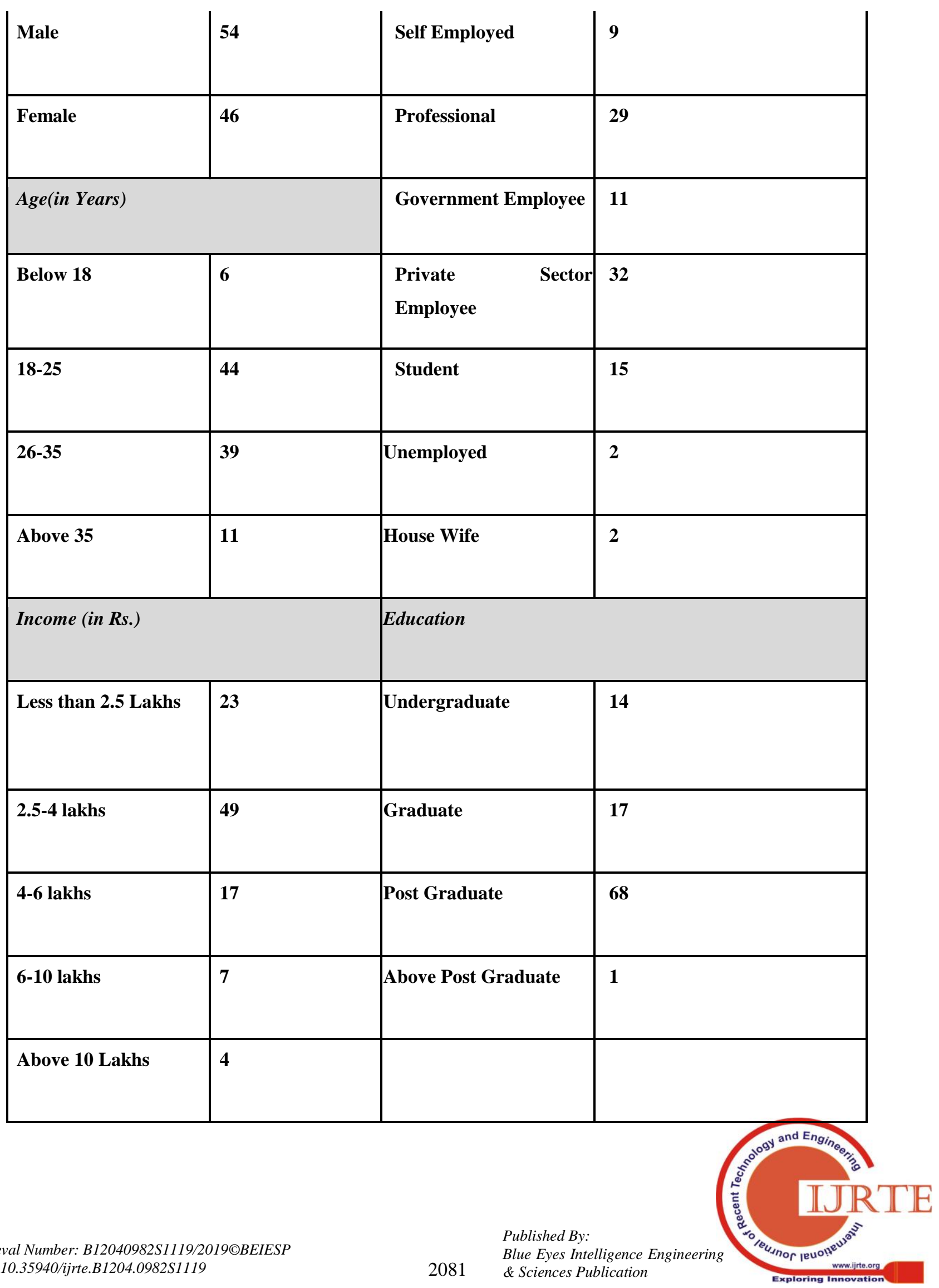


Influence of Store Atmospherics on Impulse Buying Behavior

*IBB: Impulse Buying Behavior; DF : Design Factors; SF : Social Factors

\begin{tabular}{|c|c|c|c|c|c|c|}
\hline $\begin{array}{c}\text { Predictor } \\
\text { Variable }\end{array}$ & $\mathbf{R}$ & $\begin{array}{c}\text { Adjusted R } \\
\text { Square }\end{array}$ & Constant & $\begin{array}{c}\text { Regression } \\
\text { Coefficient }\end{array}$ & P Value & Result \\
\hline $\begin{array}{c}\text { Design } \\
\text { Factors }\end{array}$ & 0.415 & 0.168 & 14.511 & 0.567 & 0.000 & $\begin{array}{c}\text { Significant Influence on } \\
\text { IBB } \\
\text { Social }\end{array}$ Factors \\
\hline
\end{tabular}

*Dependent Variable:-Impulse Buying Behavior

Influence of Design Factors on Impulse Buying Behavior

$\mathrm{R}$ Value $=0.415$, Design Factors has a moderate positive correlation on IBB

Adjusted R Square $=0.168,16.8 \%$ of variability in IBB can be explained by Design factors of Store Atmospherics.

Hence the Equation is $\mathrm{IBB}=\mathbf{1 4 . 5 1 1}+\mathbf{0 . 5 6 7} \mathrm{DF}$
Influence of Social Factors on Impulse Buying Behavior

$\mathrm{R}$ Value $=0.156$, Social Factors has a low positive correlation on IBB

Adjusted R Square $=0.020$, only $2 \%$ of variability in IBB can be explained by Social factors of Store Atmospherics.

Hence the Equation is IBB $=\mathbf{4 3 . 4 8 7}-\mathbf{0 . 4 0 8} \mathrm{SF}$

Influence of Independent constructs of Design Factors on Impulse Buying Behavior

*L - Lighting; M - Music; C -Colour

\begin{tabular}{|c|c|c|c|c|c|c|}
\hline $\begin{array}{c}\text { Predictor } \\
\text { Value }\end{array}$ & $\mathbf{R}$ & $\begin{array}{c}\text { Adjusted R } \\
\text { Square }\end{array}$ & Constant & $\begin{array}{c}\text { Regression } \\
\text { Coefficient }\end{array}$ & P Value & Result \\
\hline Lighting & .013 & .000 & 34.441 & -.047 & .839 & $\begin{array}{c}\text { Insignificant Influence } \\
\text { on IBB }\end{array}$ \\
\hline Music & .474 & .221 & 16.989 & 1.229 & .000 & $\begin{array}{c}\text { Significant Influence on } \\
\text { IBB }\end{array}$ \\
\hline Colour & .365 & .129 & 22.461 & 1.067 & .000 & $\begin{array}{c}\text { Significant Influence on } \\
\text { IBB }\end{array}$ \\
\hline
\end{tabular}

* Dependent Variable:-Impulse Buying Behavior

Influence of Lighting on Impulse Buying Behavior

$\mathrm{R}$ Value $=0.013$, Lighting has no correlation on IBB

Influence of Music on Impulse Buying Behavior

$\mathrm{R}$ Value $=0.474$, Music has a Moderate positive correlation on $I B B$

Adjusted R Square $=0.221,22.1 \%$ of variability in IBB can be explained by Music played in the Store.
Hence the Equation is $\mathbf{I B B}=\mathbf{1 6 . 9 8 9}+\mathbf{1 . 2 2 9} \mathrm{M}$

Influence of Colour on Impulse Buying Behavior

$\mathrm{R}$ Value $=0.365$, Colour has a Moderate positive correlation on IBB

Adjusted R Square $=0.129$, only $12.9 \%$ of variability in IBB can be explained by Colour theme of the Store.

Hence the Equation is $\mathrm{IBB}=\mathbf{2 2 . 4 6 1}+\mathbf{1 . 0 6 7} \mathrm{C}$ 
Influence of Independent constructs of Social Factors on Impulse Buying Behavior

* E - Employees; CC - Customer Crowding

\begin{tabular}{|c|c|c|c|c|c|c|}
\hline Predictor Value & R & $\begin{array}{c}\text { Adjusted R } \\
\text { Square }\end{array}$ & Constant & $\begin{array}{c}\text { Regression } \\
\text { Coefficient }\end{array}$ & P Value & Result \\
\hline Employees & .092 & 0.004 & 38.232 & -0.332 & 0.162 & $\begin{array}{c}\text { Insignificant } \\
\text { Influence on IBB }\end{array}$ \\
\hline $\begin{array}{c}\text { Customer } \\
\text { Crowding }\end{array}$ & 0.179 & 0.032 & 43.756 & -0.930 & 0.006 & $\begin{array}{c}\text { Significant Influence } \\
\text { on IBB }\end{array}$ \\
\hline
\end{tabular}

\section{* Dependent Variable:-Impulse Buying Behavior}

Influence of Store Employees on Impulse Buying Behavior $B B$

$\mathrm{R}$ Value $=0.092$, Store employees has no correlation on

\section{Influence of Customer Crowding on Impulse Buying} Behavior

$\mathrm{R}$ Value $=0.179$, Customer crowding has a low positive correlation on $I B B$

Adjusted R Square $=0.032$, only $3.2 \%$ of variability in IBB can be explained by Customer crowding in the Store.

Hence the Equation is IBB $=43.756-0.930 ~ C C$

\section{LIMITATIONS AND DISCUSSIONS\& RESULTS}

The study is limited only to Kottayam District in Kerala. Therefore the sample is very small for any conclusion. From the study it is clear that besides design and ambient factors there are some more factors which has to be considered as an attribute for store atmospherics. In the study it is clear that social factors does not have much influence on Impulse Buying Behavior it can be concluded that employees create induced buying behaviour.Demography is not considered in the study.That becomes another limitation. It is recommended to consider demographic variables like age, gender, location, family size etc. in future research on impulse buying behavior.

\section{REFERENCES}

1 A. Carida, T. R. Spena, M. Melia and Colurcio, "buying records as an outer memory assist for looking for meals: influences on rundown composing and rundown pleasure", journal of client Psychology, vol. four, no. 3 , (2010), pp. 97-117

2 Areni, C.S. And Kim, D. (1993). The impact of ambient sounds on buying conduct: antique fashion in preference to top-40 song in a wine store.Advances in customer studies, 336-340.

3 A. Sharma and T. F. Stafford "The effect of Retail Atmospherics on clients' Perceptions of Salespeople and consumer Persuasion: An Empirical investigation", magazine of business studies, vol. 49, (2000), pp. 183-191.

4 Baker, J., Grewal, D., \&Parasuraman, A. (1994). The affect of store environment on high-quality Inferences and save photograph. Diary of the Academy of marketing Sciences, 22(four), 328-339

5 Baker, J., Parasuraman, A., Grewal, D., and Voss, G. B. (2002). The affect of multiple hold environment Cues on Perceived products Valueand Patronage Intentions. Diary of advertising, 66(2), a hundred and twenty-141

6 Chebat, J.C. (1997). influences of track initiated pleasure on the evaluation of price in administrations. 6th international conference on productivity and exceptional research, 136-148

7 Dube, L., Chebat, J.C. And Sylvie, M. (1995). The affects of mood melodies on buyers. need to associate in purchaser vender interactions.Psychology and marketing, 12, 305-319.

8 Dube, L., Chebat, J.C. And Sylvie, M. (1995). The impacts of mood melodies on consumers. want to associate in purchaser vender interactions.Psychology and advertising, 12, 305-319.

9 D. W. Rook and R. J. Fisher, "Regulating influences on incautious buying", magazine of customer research, vol. 22, no. 3, (1995), pp. 305-313.

10 D. W. Rook, "The buying motivation", magazine of purchaser research, vol .14, no. 2, (1987), pp. 189-199

11 Greeland and McGoldrick," Atmospherics, Attitudes and conduct: Modeling the impact of Designed space", The global assessment of Retail Distribution and consumer research four(1):1-sixteen

12 Hui, M.k. And Bateson, E.G. (1991). seen manage and the influences of swarming and customer choice at the control enjoy. Diary of purchaser studies, 18, 174-184.

13 H. Skandrani, N. B. D. Mouelhi and F. Malek, "effect of save atmospherics on personnel' responses", global journal of Retail and Distribution management, vol. 39, no. 1, (2011), pp. fifty one-67

14 J. Dough puncher, D. Grewal and A. Parasuraman, "The have an impact on of shop environment on great Inferences and save picture", journal of the Academy of advertising technology, vol. 22, no. four, (1994), pp. 328-339.

15 Joo Park, Eun, Eun young Kim, and Judith Cardona Forney. "A simple model of fashion positioned energy buying behavior." journal of favor advertising and control: An international journal 10, no. four (2006): 433-446 
16 . ok. Yildirim, A. Akalin and M. L. Hidayetoglu, "The effects of the shop Window type on purchasers' notion and purchasing Attitudes thru the usage of digital pics", G. U. Diary of technology, vol. 20, no. 2, (2007), pp. 33-forty.

17 L. Aron, "Does tv Viewing have an impact on store picture and purchasing Frequency", magazine of Retailing, vol. 37, no. 1, (1961), pp. 1-thirteen.

18 L. W. Turley and R. E. Milliman, "Climatic consequences on buying behavior: A evaluation of The Empirical proof", journal of commercial enterprise research, vol. 40 nine, (2007), pp. 193-211

19 Parboteeah, D. V., 2005. A model of online drive buying: An specific research. Doctoral thesis Washington country college

20 Park, EunJoo, Eun younger Kim, Venessa Martin Funches, and William Foxx. "apparel object homes, net perusing, and e-motivation purchasing on buying web sites." magazine of enterprise research sixty 5, no. 11 (2012): 1583-1589.

21 . P. Martineau, "The persona of the Retail shop", Harvard enterprise review, vol. 36, no. 1, (1958), pp. 47-fifty six.

22 Sharma,Stanfford," The impact of Retail Atmospherics on customers' Perceptions of Salespeople and consumer Persuasion: An Empirical research", magazine of business studies, Vol . 40 nine, (2000), Pp 183-191

23 Sultan, Abdullah J., Jeff Joireman, and David E. Sprott. "building purchaser poise: The effect of discretion practices on strength buying urges." advertising Letters 23, no. 1 (2012): 61-seventy two.

24 S. E. Beatty and M. E. Ferrell, "force buying: demonstrating its antecedents, journal of Retailing, vol. seventy four, (1998), pp. 169-191.

25 Titus, P.A. And Everett, P.B. (1995). The patron retail are seeking system: an less expensive model and studies plan. Diary of the Academy of advertising technological know-how, 23(2), forty six-sixty one

26 Tinne, WahidaShahan. "factors influencing motivation buying behavior of clients at superstores in Bangladesh." ASA university review five, no. 1 (2011): 209-220.

27 Tifferet, Sigal, and Ram Herstein. "Sexual orientation contrasts in logo duty, force buying, and epicurean usage." journal of Product and logo management 21, no. three (2012): 176-182.

28 Vohs, Kathleen D., and Ronald J. Faber. "Spent property: Self-administrative asset accessibility impacts motivation buying." magazine of purchaser inquire about 33 , no. four (2007): 537-547.

29 Vohs, ok., and Ronald Faber, R., 2003."Self-regulation and Impulsive Spending patterns", in NA - Advances in customer research extent 30, Eds. Pages: 100 twenty $5-126$. 